\title{
Determination of Carnosine, Anserine, and Balenine in the Muscle of Animal
}

\author{
Michizo Suyama, Takeshi Suzuki, Michie Maruyama, and Kaoru SaIto* \\ (Received May 25, 1970)
}

\begin{abstract}
Carnosine ( $\beta$-alanylhistidine) is one of the most popular constituents of the animal tissues. Of the derivatives carring a methyl group in the imidazole moiety, anserine ( $\beta$-alanyl-1-methylhistidine) and balenine ( $\beta$-alanyl-3-methylhistidine) have been known to occur in the muscles of some animals. Ophidine, first reported erroneously to correspond to $\beta$-alanyl-2-methylhistidine, has been proved to be identical with balenine by the analysis of nuclear magnetic resonance spectra ${ }^{13}$.

Shortly after carnosine and anserine were discovered, many analytical data obtained by earlier methods of isolation and assay on various animal tissues were reported, and most of them published before 1938 were summarized by Du VIGNEAUD and BEHRENs ${ }^{2}$. The chromatographic determination of carnosine and anserine was made by DAVEY ${ }^{3)}$ and SPACKMAN et al. ${ }^{4)}$ However, our knowledge concerning the distribution of the compounds is still regrettably deficient because of unsatisfactoriness of the analytical methods, thus, during an investigation on the sample including balenine, the present authors ${ }^{5}$ noticed that balenine elutes with carnosine or anserine from the columns adopted in the above methods. An attempt to determine these three compounds and analytical data on the muscles of whales have been described previously ${ }^{5}$.

The purpose of the present study is to investigate the distribution of carnosine, anserine, and balenine in various specics of the vertebrate and invertebrate. The details together with an additional proposal on the procedure of column chromatography are given below.
\end{abstract}

\section{Experimental}

Materials. The following species of animals, representing some quite different biological types, were examined; mammals (23 specimens), domestic fowl (1), snakes (3), fishes (28), crustaceans (3), molluscs (6), and sea cucumber (1). No attempt was made to distinguish the sex or age of the individuals. In the case of vertebrate, the muscle was obtained from the dorsal part of body except the case of a domestic fowl in which a sample was obtained from the thigh. With invertebrate, whole meat (crab and sea cucumber),

* Tokyo University of Fisheries, Konan, Minato-ku, Tokyo (須山三千三・鉿木 健 ·丸山美智惠 济藤 蒸: 東京水産大学) 
abdominal meat (shrimp), trunk of the body (squid), foot part (shellfish), and arms (octopus) were used.

Preparation of extractives. The preparation method used was essentially the same as that given in the previous paper ${ }^{5)}$. The extractives were evaporated to small volume in a rotary evaporator, and kept in the frozen state until used.

Chromatography of carnosine, anserine, and balenine. The chromatographic technique of Spackman et al. ${ }^{4)}$ using a column of Amberlite IR-120 $(0.9 \times 50 \mathrm{~cm})$ was used throughout. To improve the resolution of the compounds from the column, the $\mathrm{pH}$ value of buffer solution was changed to 4.06 as described ${ }^{51}$, and the temperature of column was elevated to $50^{\circ} \mathrm{C}$ as suggested from the data of Fig. 1-A of the present paper.

\section{Results and Discussion}

Effects of temperature and $\mathrm{pH}$ of buffer solution on resolution of carnosine, anserine, and balenine from a $50 \mathrm{~cm}$ column of Amberlite IR-120. It has been shown that several imidazole compounds and basic amino acids are eluted separately from a $50 \mathrm{~cm}$ column of Amberlite IR-120 by use of $0.38 \mathrm{~N}$ sodium citrate buffer of $\mathrm{pH} 4.06$ at $30^{\circ} \mathrm{C}^{\text {s) }}$. When
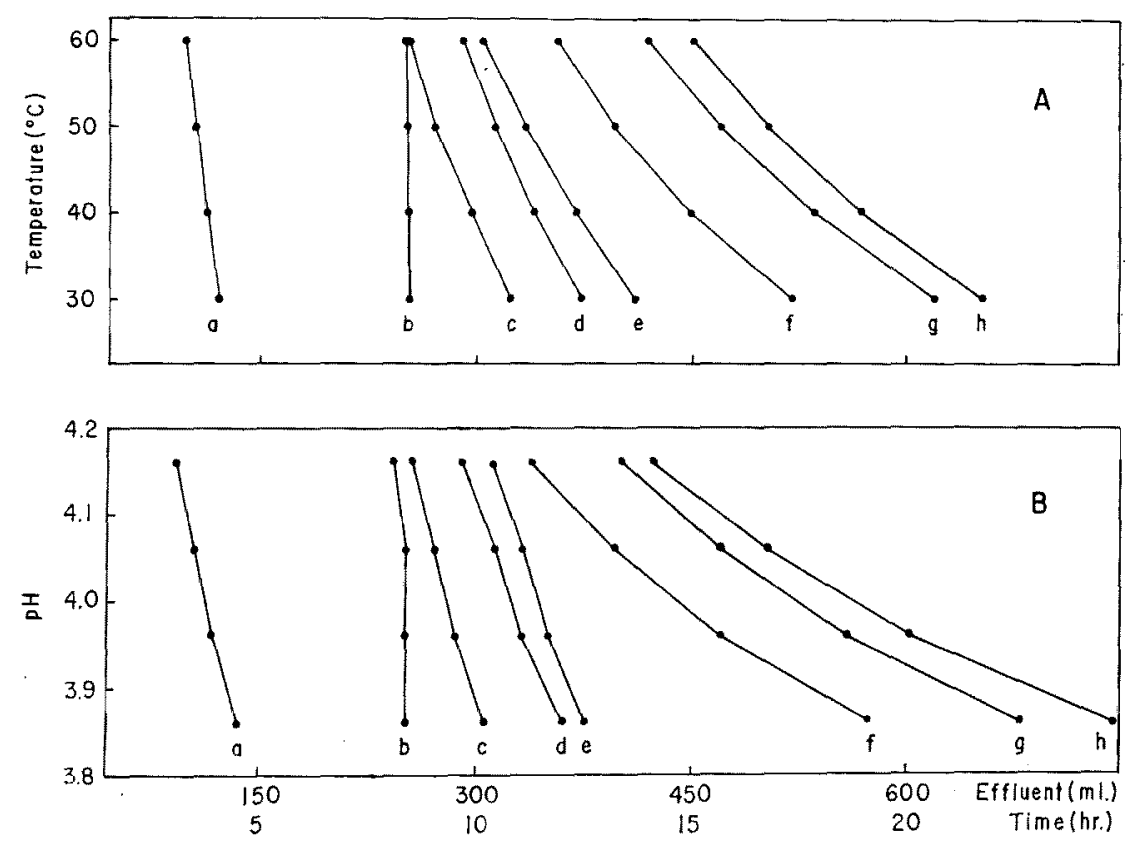

Fig. 1. Effects of temperature and $\mathrm{pH}$ on resolution of basic amino acids, carnosine, anserine, and balenine from a $50 \mathrm{~cm}$ column of Amberlite IR-120 using $0.38 \mathrm{~N}$ sodium citrate buffer.

A: $\mathrm{pH} 4.06$, at $30-60^{\circ} \mathrm{C}$. B: $\mathrm{pH} 3.86-4.16$, at $50^{\circ} \mathrm{C}$.

\begin{tabular}{|c|c|}
\hline a $\beta$-Alanine & b Ammonia \\
\hline c 1-Methylhistidine & d Histidine \\
\hline e 3-Methylhistidine & f Anserine \\
\hline g Balenine & h Carnosine \\
\hline
\end{tabular}


sample rich in one of the compounds was analyzed, however, the peak concerned became broader and gave a steep acclivity at the beginning of its emergence. To obtain more sutable chromatographic conditions, the influence of temperature on resolution was examined. The results are shown in Fig. 1-A.

It is apparent that as the temperature is changed the position of each compounds is shifted. The relative positions of carnosine, anserine, and balenine on the chromatograms are little altered, however, the width of each peak narrows at a high temperature so that the excellence of the resolution is obtained. At $50^{\circ} \mathrm{C}$, resolution is adequate, and carnosine is not unduly retarded. In Fig. 1-B, the resolution at $50^{\circ} \mathrm{C}$ with citrate buffers having $\mathrm{pH}$ from 3.96 to 4.26 is illustrated for the comparison with that obtained at $30^{\circ} \mathrm{C}^{5}$.

Distribution of carnosine, anserine, and balenine in the muscles of various species of animals. The amounts of carnosine, anserine, and balenine in the muscle extracts of animals were determined by the method using a $50 \mathrm{~cm}$ column of Amberlite IR-120 and $0.38 \mathrm{~N}$ sodium citrate buffer solution of $\mathrm{pH} 4.06$ at $50^{\circ} \mathrm{C}$.

Table 1 represents the distribution of the compounds in various species of vertebrate except the fishes. The significant feature of the results is the variation in the distribution of these compounds. It was found that the muscles of ox and pig contained large amounts of carnosine, and the former was lacking in balenine. Among the whales, each specimen of the fin, sei, and little piked whales, which belong to the baleen whales, had the highest amount of balenine, intermediate amount of carnosine, and relatively small amount of anserine. In the teethed whales, on the other hand, the pattern seemed to be unlike: The sperm whale contained high amounts of carnosine and anserine, but the pilot whale and common dolphin were rich in carnosine and balenine. With harbor seal, a large amount of carnosine and an intermediate amount of anserine were found.

In the case of domestic fowl, anserine, as well as carnosine, was the important imidazole. Both compounds were present in quantities amounting to $1400 \mathrm{mg} \%$ in all, and the figure ranked next to those of baleen whales and albacore. In the snakes examined, carnosine and balenine were detected in relatively high concentration, however, the pattern of their range varied with the species. It may be noted in this connection that the specimen of snake was obtained after about one month after the hibernation.

Table 2 shows the analytical results of several species of fishes. It can be seen from the table that the fish include some distinct groups so far as the distribution is concerned. Among the elasmobranchs, the muscle of Carcharhinus longimanus contained the three compounds, Isurus glaucus had anserine, however, Musterus manazo was lacking in all these compounds.

A species belonging to the tuna family seemed to be rich in anserine, and some specimens contained small amount of carnosine and/or balenine. LUKTON and OLCOTT ${ }^{6)}$ have made similar suggestions, although the analytical method conformed to that of 
Table 1. Distribution of carnosine, anserine, and balenine in the muscle of mammals, domestic fowl, and snakes.

$(\mathrm{mg} \%)$

\begin{tabular}{|c|c|c|c|}
\hline & Carnosine & Anserine & Balenine \\
\hline \multicolumn{4}{|l|}{ Mammalia } \\
\hline Ox, Bos taurus & 230 & 16.5 & 0 \\
\hline Pig, Sus scrofa v. domesticus & 387 & 30.7 & 41.9 \\
\hline \multicolumn{4}{|l|}{ Baleen whales } \\
\hline \multirow[t]{4}{*}{ Fin whale, Balaenoptera physalus } & 140 & 5.0 & 1500 \\
\hline & 103 & 4.4 & 1510 \\
\hline & 112 & 4.3 & 1340 \\
\hline & 134 & 2.8 & 1520 \\
\hline \multirow[t]{4}{*}{ Sei whale, Balaenoptera borealis } & 131 & 6.4 & 1840 \\
\hline & 272 & 18.2 & 1560 \\
\hline & 138 & 7.5 & 1930 \\
\hline & 300 & 8.8 & 1700 \\
\hline Little piked whale, Balaenoptera & 154 & 22.7 & 1930 \\
\hline \multirow[t]{2}{*}{ acutorostrata } & 117 & 49.3 & 1700 \\
\hline & 131 & 31.5 & 1990 \\
\hline \multicolumn{4}{|l|}{ Teethed whales } \\
\hline \multirow[t]{4}{*}{ Sperm whale, Physeter catodon } & 196 & 126 & 3.2 \\
\hline & 206 & 83.6 & 1.8 \\
\hline & 232 & 137 & 0.8 \\
\hline & 235 & 133 & 1.2 \\
\hline \multirow[t]{2}{*}{ Pilot whale, Globicephala melaena } & 227 & 39.0 & 515 \\
\hline & 275 & 37.5 & 590 \\
\hline \multirow[t]{2}{*}{ Common dolphin, Delphinus delphis } & 447 & 92.7 & 489 \\
\hline & 384 & 166 & 766 \\
\hline \multirow[t]{2}{*}{ Harbor seal, Phoca viturina } & 592 & 150 & 0 \\
\hline & 511 & 118 & 0 \\
\hline \multicolumn{4}{|l|}{ Aves } \\
\hline Domestic fowl, Gallus gallus v. domesticus & 439 & 956 & 0 \\
\hline \multicolumn{4}{|l|}{ Reptilia } \\
\hline \multicolumn{4}{|l|}{ Snakes } \\
\hline Elaphe quadrivirgata & 22.1 & 2.8 & 391 \\
\hline Natrix tigrina tigrina & 209 & 1.2 & 111 \\
\hline Agistrodon halys blomhoffii & 140 & 2.7 & 74.4 \\
\hline
\end{tabular}

DAVEY $^{3)}$. The dark-fleshed fish such as sardine, pacific saury, pacific mackerel, horse mackerel, which are known to be rich in histidine, were practically lacking in carnosine, anserine, and balenine. The light muscle was higher in anserine content than the dark muscle as shown in the analyses of albacore and sardine. A relatively high amount of carnosine of the eel was in good agreement with that reported by KoNOSU et al. ${ }^{\text {? }}$

Table 3 shows the results of several species of invertebrate. It will be noted from 
Table 2. Distribution of carnosine, anserine, and balenine in the muscle of fishes.

(mg\%)

\begin{tabular}{|c|c|c|c|}
\hline & Carnosine & Anserine & Balenine \\
\hline \multicolumn{4}{|l|}{ Pisces } \\
\hline \multicolumn{4}{|l|}{ Elasmobranchs } \\
\hline \multirow[t]{3}{*}{ Glyphis glaucus } & 0 & 22.6 & 2.3 \\
\hline & 0 & 34.3 & 3.6 \\
\hline & 0 & 28.3 & 2.5 \\
\hline Carcharhinus longimanus & 50.3 & 284 & 29.9 \\
\hline Isurus glaucus & 0 & 872 & 2.9 \\
\hline Mustelus manazo & 0 & 0 & 0 \\
\hline Squalus mitsukurii & 0.4 & 1010 & 0.3 \\
\hline Dasyatis akajei & 0 & 2.3 & 0 \\
\hline \multicolumn{4}{|l|}{ Teleosts } \\
\hline \multirow[t]{2}{*}{ Bigeye tuna, Tunnus obesus } & 0 & 859 & 0 \\
\hline & 0 & 1590 & 10.9 \\
\hline Yellowfin tuna, Thunnus albacares & 9.5 & 1090 & 6.5 \\
\hline Albacore, Thunnus alalunga & 0.2 & 1570 & 0 \\
\hline (ordinary meat) & 0.2 & 1200 & 0 \\
\hline (dark meat) & 0 & 398 & 0 \\
\hline Southern bluefin, Thunnus maccoyii & 0 & 735 & 0 \\
\hline \multicolumn{4}{|l|}{ Sardine, Sardinops melanosticta, } \\
\hline (ordinary meat) & 0 & 4.3 & 0 \\
\hline (dark meat) & 0 & 0.1 & 0 \\
\hline \multicolumn{4}{|l|}{ Pacific saury, Cololabis saira, } \\
\hline (ordinary meat) & 0 & 0 & 0 \\
\hline (dark meat) & 0 & 0 & $\mathbf{0}$ \\
\hline \multicolumn{4}{|l|}{ Pacific mackerel, Scomber japonicus } \\
\hline (ordinary meat) & 0 & 0 & 0 \\
\hline (dark meat) & 0 & 0 & 0 \\
\hline Horse mackerel, Trachurus japonicus & 0 & 2.6 & 0 \\
\hline Eel, Anguilla japonica & 542 & 0 & 0 \\
\hline Sea perch, Lateolabrax japonicus & 0.1 & 0 & 0.4 \\
\hline Red sea bream, Pagrus major & 0 & 1.8 & $\mathbf{0}$ \\
\hline Flat fish, Kareius bicoloratus & 0 & 0 & 0 \\
\hline "Takabe", Labracoglossa argentiventris & 0 & 0 & $\mathbf{0}$ \\
\hline
\end{tabular}

the table that carnosine, anserine, and balenine are not distributed in molluscs, crustaceans, and sea cucumber so far examined except for only small amounts of carnosine and anserine are found in the crab, Portunus trituberculatus.

\section{Summary}

The ion-exchange method of SPACKMAN et al. for determining the basic amino acids as well as carnosine and anserine was modified so that it is applicable to samples including 
Table 3. Distribution of carnosine, anserine, and balenine in the muscle of crustaceans, molluses, and sea cucumber.

\begin{tabular}{|c|c|c|c|}
\hline & Carnosine & Anserine & Balenine \\
\hline \multicolumn{4}{|l|}{ Crustacea } \\
\hline Shrimp, Metapenaeus joyneri & 0 & 0 & 0 \\
\hline Penaeus orientalis & 0 & 0 & 0 \\
\hline Crab, Portunus trituberculatus & 2.9 & 2.8 & 0 \\
\hline \multicolumn{4}{|l|}{ Lamellibranchia } \\
\hline Hard clam, Meretrix lusoria & 0 & 0 & 0 \\
\hline Gaper, Schizothaerus keenae & 0 & 0 & 0 \\
\hline \multicolumn{4}{|l|}{ Gastropoda } \\
\hline Top-shall, Turbo (Batillus) cornutus & 0 & 0 & 0 \\
\hline Abalone, Haliotis gigantea & 0 & 0 & 0 \\
\hline \multicolumn{4}{|l|}{ Cephalopoda } \\
\hline Squid, Todarodes pacificus & 0 & 0 & 0 \\
\hline Doryteuthis bleekeri & 0 & 0 & 0 \\
\hline Octopus, Octopus ocellatus & 0 & 0 & 0 \\
\hline \multicolumn{4}{|l|}{ Holothroidea } \\
\hline Sea cucumber, Stichopus japonicus & 0 & 0 & 0 \\
\hline
\end{tabular}

balenine, and the method using a $50 \mathrm{~cm}$ column of Amberlite IR-120 and $0.38 \mathrm{~N}$ citrate buffer solution of $\mathrm{pH} 4.06$ at $50^{\circ} \mathrm{C}$ was recommended.

The survey of carnosine, anserine, and balenine on the muscle extracts of various animals (mammals, 23 specimens; domestic fowl, 1; snakes, 3; fishes, 28; crustaceans, 3 ; molluscs, 6; and sea cucumber, 1) was undertaken in order to obtain unequivocal information about the distribution of these compounds, and it was found that considerabls differences in the pattern exist among the species of animals.

\section{References}

1) M. Suyama and M. Maruyama: This Bull., 35, $471-478$ (1969); J. Biochem., 66, $405-407$ (1969).

2) V. Du Vigneaud and O. K. Behrens: Ergebn. Physiol., Biol. Chem. exp. Pharmakol., 41, 917973 (1939).

3) C. L. DAvEY: Nature, 179, 209-210 (1957).

4) D. H. Spackman, W. H. Stein, and S. Moore: Anal. Chem., 30, 1190-1206 (1958).

5) M. Suyama, T. SuzuKi, and J. NonAKA: This Bull, 33, 141-146 (1967).

6) A. Lukton and H.S. Olcott: Food Res., 23, 611-618 (1958).

7) S. Konosu, M. ÖZaY, and Y. Hashimoto: This Bull., 30, 930-934 (1964). 